\title{
FREKUENSI CEDERA ATLET PELATDA SEPATU RODA (PERSEROSI DIY)
}

\section{Oleh:}

Yoga Bagaswara dan Bambang Priyonoadi

\section{Pendididkan Kesehatan dan RekreasiFIK UNY}

\section{Abstrak}

Sepatu roda merupakan olahraga modern yang yang sedang berkembang di Yogyakarta. Tim Pra PON Perserosi DIY memiliki 16 atlet yang akan di berangkatkan dalam ajang tersebut. Suatu hari peneliti diminta untuk membantu melatih Club sepatu roda EMIC Sleman. Ketika awal melatih banyak atlet yang mengeluhkan sakit atau nyeri di bagian betis dan lutut, dan juga ketika peneliti mengamati pertandingan sepatu roda di ajang HB X cup Mei 2014 peneliti melihat ada beberapa atlet yang mengalami kecelakaan ketika pertandingan atau race dilangsungkan. Sampai saat ini potensi cedera yang terjadi pada atlet sepatu roda belum diketahui untuk itu penelitian ini dilakukan.Penelitian ini bertujuan untuk mengetahui frekuensi cedera yang terjadi pada atlet sepato roda.

Penelitian ini merupakan penelitian deskriptif yang menggunakan metode survey.Sampel dalam penelitian ini adalah 16 orang atlet yang tergabung dalam Tim Pra Pon 2015 Perserosi DIY.Penelitian ini mengidentifikasi tingkat potensi cedera dapat yang terjadi pada atlet sepatu roda.Teknik pengambilan data menggunakan angket dengan jumlah 67 butir pertanyaan meliputi lokasi dan jenis cedera, faktor penyebab cedera, waktu kejadian, dan juga alat keamanan yang digunakan.Analisis data menggunakan analisis data deskriptif persentase.

Hasil penelitian menunjukan bahwa cedera yang terjadi pada atlet sepatu roda meliputi cedera ankle $18 \%$, lutut $18 \%$, tungkai bawah $14 \%$, tungkai atas $13 \%$, siku 12 $\%$, jari dan pergelangan tangan $12 \%$, pinggang $7 \%$, panggul $5 \%$. Cedera yang terjadi disebabkan karena karena terpeleset $14 \%$, kondisi cuaca $13 \%$, kondisi lintasan $13 \%$, bentuk lintasan $12 \%$, tabrakan antar atlet $11 \%$, salah mengambil tikungan $11 \%$, latihan berat terlalu lama $11 \%$, kondisi sepatu roda $9 \%$ yang terakhir karena menabrak pagar pembatas lintasan $7 \%$. Terjadinya cedera banyak terjadi saat latihan onskate $35 \%$, race $25 \%$, warm-up $22 \%$, dan saat latihan (dryland/offskate) $18 \%$. Alat kemanan yang sering digunakan Helm $42 \%$, sarung tangan $33 \%$, kacamata $11 \%$, knee pad $9 \%$, dan elbow pad $5 \%$.

Kata kunci: Frekuensi, cedera, atlet sepatu roda

Olahraga modern yang sedang berkembang di Indonesia saat ini dan khususnya di DIY adalah olahraga inline skate atau yang lebih dikenal dengan sepatu roda. DIY mempunyai dua klub sepatu roda yang sering mengikuti kejuaraan nasional, yakni Elang Merapi Inline Skate Club (EMIC) dengan homebase di Stadion Maguwoharjo dan Mataram Inline Skate Club (MIC) dengan homebase di Stadion Mandala Krida. Pada suatu kesempatan peneliti pernah di panggil oleh tim EMIC untuk menjadi masseur tim, karena pada saat itu beberapa atlet 
mengalami cedera pada otot quadricep, lutut dan juga ankle. Pada saat latihan off skate banyak melakukan lompatan dalam teknik gerakannya sehinggajika salah dalam melakukan gerakan tersebut dapat menimbulkan cedera, selain itu proses warm-up dan stretching yang dilakukan hanya sedikit yang mengenai otot-otot yang di gunakan untuk mendukung gerakangerakan teknik tersebut.

Dari hasil pengamatan di lapangan, ditemukan beberapa fakta cedera yang terjadi pada olahraga sepatu roda yaitu: (1) Atlet sepatu roda banyak menggunakan bagian ekstrimitas bawah tubuh untuk melakukan gerakan. (2) Teknik yang ada dalam sepatu roda banyak melakukan gerakan mendorong untuk memperoleh gerakan dan kecepatan yang maksimal yang menggunakan sendi panggul, lutut, otot paha dan betis. (3) Dorongan yang maksimal bertumpu pada sendi panggul, lutut dan juga otot paha dan betis. (5) Olahraga sepatu roda berisiko terhadap tabrakan antar atlet, karena luncuran yang cepat namun tidak dilengkapi dengan alat untuk mengerem. (6) Lintasan yang kurang bersih dapat menimbulkan kecelakaan pada atlet. (7) Saat pertandingan khususnya, atlet harus ekstra hati-hati dalam menghadapi tikungan karena apabila salah mengambil timing untuk menikung di kecepatan yang tinggi maka potensi untuk melebar keluar dan menabrak pagar pembatas lintasan sangat tinggi. (8) Pemahaman atlet untuk mengikuti seluruh rangkaian program latihan masih kurang. (9) Pemberian pengetahuan mengenai teknik, taktik, dan strategi saat bertanding diperlukan oleh pelatih supaya atlet dapat melakukan apa yang di instruksikan pelatih dengan benar. (10) Proses stretching dan warm up harus di sesuaikan dengan program latihan.

Berdasarkan kejadian yang terjadi diatas, banyak hal mengenai cedera yang terjadi pada atlet sepatu roda baik disaat latihan maupun saat perlombaan. Cedera-cedera diatas diakibatkan oleh banyak faktor mulai dari sarana, alat, cuaca, dan berbagai macam faktor yang lain. Oleh sebab itu peneliti ingin lebih dalam lagi mengamati dan meneliti tentang macam dan penyebab cedera yang terjadi dengan melakukan'Identifikasi Cedera Atlet Sepatu Roda" karena masih kurangnya penelitian mengenai cedera yang terjadi pada atlet sepatu roda.Menurut pakar olahraga identifikasi pada cedera olahraga sendiri merupakan proses mencari tahu atau mengenali cedera yang terjadi pada aktivitas olahraga baik secara umum maupun secara kecabangan, berdasarkan faktor penyebab, gejala maupun hal-hal yang lain.Identifikasi cedera pada atlet sepatu roda di lakukan untuk mengenali cedera yang terjadi pada olahraga sepatu roda serta mengetahui penyebab cedera dan dapat menentukan tindakkan pencegannya. 


\section{KAJIAN PUSTAKA}

\section{Hakekat Cedera}

Orang yang beraktivitas berat sangat rentan untuk mengalami cedera. Cedera merupakan kondisi dimana tubuh tidak mampu lagi untuk berkativitas seperti biasanya karena adanya gangguan pada anggota tubuh. Dalam bukunya, Ali Satia Graha dan Bambang Priyonoadi (2009: 45) menuliskan bahwa cedera adalah kelainan yang terjadi pada tubuh sehingga fungsi tendon, otot dan persendian menurun akibat aktivitas gerak yang berlebih atau kecelakaan.

Pada atlet yang mempunyai jam tanding yang sangat padat cedera menjadi salah satu momok yang selalu membayangi mereka, cedera pada talet ini sering disebut juga cedera olahraga.Cedera olahraga yaitu cedera yang terjadi pada saat latihan maupun bertanding, cedera ini terjadi pada sistem integumen, otot, dan juga rangka tubuh (Novita Intan, 2010: 3). Dalam bukunya mencegah dan mengatasi cedera olahraga Taylor(2002: 5) menuliskan:Ada dua jenis cedera yang sering dialami oleh atlet: yaitu trauma akut dan sindrom yang berlarutlarut, overuse syndrome. Trauma akut adalah suatu cedera berat yang terjadi secara mendadak, seperti cedera goresan, robek pada ligamentum, atau patah tulang karena terjatuh. Cedera akut tersebut biasanya memerlukan pertolongan yang profesional dengan segera. Banyak sekali permasalahan yang sering dialami atlet olahraga, tidak terkecuali dengan sindrom ini. Sindrom ini bermula dari adanya suatu kekuatan abnormaldalam level yang rendah atau ringan, namun berlangsung secera berulang-ulang dalam jangka waktu lama. Jenis cedra ini memberikan respon yang baik bagi pengobatan sendiri.

\section{Tingkat dan Macam Cedera}

Tingkat cedera pada olahraga dapat dilihat dari berat atau ringannya proses terjadi cedera tersebut. Menurut Brad Walker yang di kutip oleh Cerika Rismayanthi (2014) menjelaskan jenis cedera yang terjadi dalam olahraga secara umum dibagi menjadi tiga yakni:

1. Cedera olahraga ringanakanmengakibatkan sedikit rasa sakitdanpembengkakan. Tingkat ini tidak akanmempengaruhi kinerja saat berolahraga, tidak mangalami perubahan bentuk apapun.

2. Cedera olahraga sedang akan menghasilkan rasa sakit dan pembengkakan. Tingkat ini akan mempengaruhi kinerja saat olahraga dan daerah yang terkenaakan sedikit sakit bila disentuh. Sedikit perubahan warna akan terjadi pada daerah yang cedera

3. Cederaolahragaberatakan menghasilkan peningkatan rasasakitdanpembengkakan. Pada tingkatan initidak hanya akanmempengaruhikinerja saat olahraga, tetapi jugaakan mempengaruhi kinerja sehari-hari. Pada daerah yang terkena cedera akan sangat sakit 
bila disentuh, sangat terlihat perubahan warna, akan akan mengalamiperubahan bentuk.

Pada saat olahraga cedera bisa terjadi, ada empat macam dan terjadi pada lima jaringan dalam tubuh yakni pada strain (otot dan tendon), fraktur (tulang), sprain (ligamen), dislokasi (persendian), dan juga luka (sayat, robek, tusuk, dan lecet).

1. Cedera otot dan tendon merupakan kelianan ataupun gangguan yang terjadi pada otot dan tendon, yaitu berupa gangguan kekakuan otot (kram) dan otot tertarik atau robek yang lebih dikenal dengan sebutan strain.. Kram atau kejang otot adalah cedera yang terjadi karena kontraksi otot dalam kurun waktu yang relatif lama dan tidak dipengaruhi kemauan (Giam \& Teh, 1993: 192). NIAMS (2009: 1) Strain adalah cedera otot atau tendon (jaringan yang menghubungkan otot ke tulang) dalam ketegangan, otot atau tendonyang ketarik atau robek, cedera ini bisa terjadi secara tiba-tiba atau penggunaan yang berlebihan karena putaran atau tekanan yang terjadi pada otot dan tendon. Cedera yang terjadi secara tiba-tiba disebabkan oleh kesalahan dalam mengangkat benda yang berat atau terlalu sering memberikan tekanan pada otot. Dalam situs resminya American Academic Of Orthopedic Surgeon (2007) menuliskan, Strain adalah cedera yang terjadi pada otot dan atau ligamen, strain yang kronis merupakan hasil dari gerakan pengulangan yang berlebih dan dalam waktu yang lama pada saat latihan sehingga waktu untuk istirahat berkurang dan menyebabkan terjadinya endapan asam laktat pada otot dan tendon. Strain akut terjadi karena adanya tekanan/pukulan langsung ketubuh, dan overstretching (peregangan otot yang berlebih).

2. Cedera ligamen merupakan cedera yang terjadi pada bagian ligamentum, yaitu gangguan berupa robekan atau tarikan pada bagian ligamen cedera ini biasanya disebut sprain. Sprain merupakan tarikan atau robekan yang terjadi pada ligamen, ligamen sendiri merupakan jaringan ikat yang berfungsi untuk menghubungkan antar tulang sehingga membentuk sebuah sendi (American Accademic OfOrthopedic Surgeons, 2007). Lynn Millar (2011: 1) menjelaskan sprain merupakan cederaligamen, yang terjadi pada jaringan ikat yang menghubungkanantar tulang, sprain dapat diklasifikasikan oleh jumlah robekan jaringan, yang berdampak pada stabilitas sendi, nyeri dan bengkak.

3. Fraktur merupakan cedera yang terjadi pada tulang cedera ini biasanya retakkan atau patah tulang karena benturan atau tekanan yang begitu kuat. Bernard Bloch (1978: 3) menjelaskan, frkatur merupakan diskontinyuitas pada tulang (patah tulang) disebabkan oleh kekerasan yang terjadi secara mendadak. Giam dan Teh (1993: 200) juga menegaskan bahwa fraktur bisa terjadi karena adanya benturan yang kuat atau cedera yang 
menghancurkan. Berdasarkan pernyataan di atas dapat ditarik sebuah inti bahwasanya fraktur merupakan cedera diskontinyuitas pada tulang yang terjadi karena adanya benturan yang kuat atau cedera yang menghancurkan.

4. Dislokasi adalah cedera yang terjadi akibat lemahnya ligamen pada persendian sehingga persendian lebih mudah untuk lepas dari sambungan antar tulang. Giam \& Teh (1993: 198) menjelaskan dalam bukunya, dislokasi merupakan "perpindahan permukaan tulang-tulang yang membentuk sendi sedemikian rupa sehingga tulang-tulang tadi tidak berhadapan lagi." Pernyataan tersebut di perkuat oleh Iskandar Junaidi (2011: 103) yang menjelasakan, dislokasi atau sendi meleset adalah keadaan dimana sendi terlepas dari tempat sendinya atau berada tidak pada tempatnya, karena sendi berada tidak pada tempatnya maka sendi menjadi kaku, sulit untuk bergerak dan terasa nyeri, cedera ini biasa terjadi pada seorang atlet.

5. Luka menurut Giam dan Teh (1993: 187) menyebutkan "suatu luka didefinisikan sebagai suatu ketidaksinambungan dari kulit dan jaringan di bawahnya yang mengakibatkan perdarahan yang kemudian dapat mengalami infeksi." Pernyataan hampir sama di utarakan oleh Iskandar Junaidi (2011: 89) yang mengatakan bahwa luka merupakan sesuatu yang terjadi pada tubuh yang diakibatkan karena benda tajam, tumpul, senjata dan lain-lain. Sehingga dari dua definisi tersebut luka merupakan ketidak sinambungan dari kulit dan jaringan dibawahnya akibat terkena benda tajam, benda tumpul, senjata dan benda lainnya. Menurut Ronald P. Pfeiffer yang di kutip oleh Cerika Rismayanthi (2014: 3) menjelaskan bahwa memar merupakan cedera yang terjadi pada jaringan dibawah permukaan kulit rusak dan pembuluh darah kecil pecah sehingga darah dan cairan seluler merembes kejaringan sekitarnya, terjadi karena benturan benda keras pada jaringan lunak tubuh.

\section{Cedera Sepatu Roda}

Olahraga selalu dekat dengan yang namanya cedera tanpa terkecuali olahraga sepatu roda. Penelitian yang dilakukan di amerika oleh Richard A. Schieber, Christine M. BrancheDorsey, and George W. Ryan (1994: 271) yang menunjukkan hasil sebagai berikut: Approximately 30863 persons (95\% confidence interval, 23073 to 38653) were treated for inline skating injuries during the study period. For every in-line skating injury, approximately 3.3 rollerskating and 1.2 skateboarding injuries occurred $(P<.0001)$. The median age of those injured in these three sports was 15, 12, and 13 years, respectively $(P<.0001)$. Sixty-three percent of injured inline skaters had a musculoskeletal injury, including $37 \%$ with a wrist injury, of which two thirds were fractures and/or dislocations. Five percent of all injured 
inline skaters had head injury and $3.5 \%$ of the injured inline skaters required hospitalization.

Pada penelitian tersebut Richard dan kawan-kawan menemukan bahwasanya $63 \%$ cedera terjadi pada sistem muskuloskeletal, dimana $37 \%$ pada pergelangan tangan dan $2 / 3$ dari itu adalah patah tulang dan atau dislokasi, $5 \%$ cedera yang lain termasuk cedera pada kepala dan 3,5 \% persen cedera terjadi membutuhkan perawatan di rumah sakit. Ada juga yang berpendapat cedera di in-line skating relatif parah, dengan $40 \%$ yang melibatkan patah tulang, Jenis tersisa adalah: lecet dan memar $-22 \%$, keseleo dan strain $-18 \%$, laserasi -13 $\%$ dan unclassified - 7 \% menurut (Michigan Governor's Council on Physical Fitness, Health and Sports).

Dari penelitian diatas menunjukkan bahwa tingkat risiko cedera yang dia alami oleh para pesepatu roda sangatlah tinggi. Pada penelitian tersebut juga menunjukkanbahwasanya banyak terjadi karena kurangnya kelengkapan keamanan yang di gunakan oleh pesepatu roda. Virak Tan dkk (2001: 691) mengatakan tentang risiko cedera sebagai berikut: “......Risk factors for injury include inexperience, aggressive skating and amount of time spent skating." Yang artinya faktor risiko cedera meliputi pengalaman, agresifisme skating, lama waktu berskating.

\section{METODE PENELITIAN}

Penelitian ini merupakan penelitian deskriptif. Penelitian ini akan mengungkapkan kasus cedera yang terjadi pada olahraga sepatu roda. Penelitian ini mengambil tempat di lapangan sepatu roda stadion Mandala Krida Yogyakarta dimana digunakanan untuk latihan tim sepadu roda pra PON DIY. Dalam penelititan ini peneliti mengambil waktu pengambilan data adalah pada saat jadwal latihan pukul $15.30 \mathrm{~s} / \mathrm{d} 17.30$ pada tanggal 25-28 Februari 2015.

Populasi dalam penelitian ini populasi adalah atlet sepatu roda di wilayah D.I. Yogyakarta. Dalam penelitian ini teknik sampling yang digunakan adalah purpose sampling, dengan mengambil sampel atlet sepatu roda Pelatda Perserosi DIY usia 13-17 tahun berjumlah 16 atlet yang akan di terjunkan dalam ajang pra PON. Instrumen yang digunakan dalam penelitian ini berupa angket quisioner. Data dalam penelitian ini merupakan data yang diperoleh dengan menggunakan metode survey yakni mengumpulkan informasi sebanyakbanyaknya dari subjek

\section{HASIL PENELITIAN}

Faktor Penyebab Cedera 
Pada faktor penyebab cedera ada sembilan indikator adapun hasilnya sebagai berikut: faktor tertinggi penyebab cedera karena terpeleset $14 \%$, kondisi cuaca $13 \%$, kondisi lintasan $13 \%$, bentuk lintasan $12 \%$, tabrakan antar atlet $11 \%$, salah mengambil tikungan $11 \%$, latihan berat terlalu lama $11 \%$, kondisi sepatu roda $9 \%$ yang terakhirkarena menabrak pagar pembatas lintasan $7 \%$.

\title{
Macam dan Jenis Cedera
}

Cedera yang dialami oleh atlet meliputi cedera ankle, lutut, tungkai bawah, tungkai atas, siku, jari dan pergelangan tangan, pinggang, panggul.Cedera tersebut merupakan kasus yang terjadi selama dilapangan baik saat latihan maupun perlombaan. Berdasar persentase tingkat cedera pada atlet sepatu roda pelatda DIY 2015 menunjukkan cedera ankle $18 \%$, lutut $18 \%$, tungkai bawah $14 \%$, tungkai atas $13 \%$, siku $12 \%$, jari dan pergelangan tangan $12 \%$, pinggang $7 \%$, panggul $5 \%$.

\section{Waktu Kejadian}

Hasil cedera yang sering dialami atlet berdasarkan waktu kejadian menunjukkan nilai sebagai berikut: Berdasarkan persentase waktu terjadinya cedera pada sepatu roda sebagai berikut, latihan onskate $35 \%$, race $25 \%$, warm-up $22 \%$, dan saat latihan (dryland/offskate) $18 \%$.

\begin{abstract}
Alat Keamanan
Alat keamanan merupakan safety gear yang sering digunakan sehingga cedera dapat diminimalisir. Data hasil penelitian menunjukkan lima jenis alat keamanan yang sering digunakan diperoleh presentase tertinggi yang sering digunakan adalah Helm $42 \%$, sarung tangan $33 \%$, kacamata $11 \%$, knee pad $9 \%$, dan elbow pad $5 \%$.
\end{abstract}

\section{PEMBAHASAN}

Penelitian dilakukan untuk mengetahui tingkat potensi cedera yang terjadi pada atlet pelatda sepatu roda perserosi D.I. Yogyakarta.Data yang diperoleh pada penelitian ini adalah dari kuisioner yang di diberikan kepada atlet yang mengikuti pemusatan latihan daerah sepatu roda. Tim pelatda saat ini diisi dengan formasi 8 atlet putra dan 8 atlet putri dengan atlet yang berusia $13-15$ ada 7 orang, dan untuk usia $>16$ ada 9 orang, sehingga total atlet yang mengikuti pemusatan latihan ada 16 atlet.

Persentase diatas hampir sama dengan hasil survey yang dilakukan di New York oleh Michael Schuster dan Alexander Israeli (1999: 7-10) yang menyatakan bahwa mayoritas 
cedera yang terjadi pada pesepatu roda adalah abrasi kulit dan musculo ligamentum dimana lokasi yang sering cedera meliputi siku, pergelangan tangan dan juga lutut. Hal yang hampir sama juga dikemukakan oleh Shauna Sherker dan Erin Cassell (2002: 13-14) menyatakan cedera yang sering dialami pada tubuh bagian atas adalah siku, pergerlangan tangan, jari, serta bahu, dan untuk tubuh bagian bawah adalah panggul, lutut, dan ankle.Meskipun sudah menggunakan kaos kaki namun luka ini bisa terjadi karena terlalu seringnya gesekan diarea tersebut atau sepatu roda yang digunakan lebih kecil dari ukuran kaki. Luka ini akan berpengaruh pada kualitas latihan ataupun hasil lomba karena luka ini membuat ketidaknyamanan seorang atlet karena harus menahan pedih akibat luka yang di timbulkan.

Memar dengan persentase $22 \%$ menunjukkan bahwa pada cedera ini riskan dengan benturan, terutama saat terjadi tabrakan di tikungan bisa posisi jatuh dari para atlet tidak terkendali sehingga seoatu rodanya menjatuhi ankle dari atlet yang lain. Kasus dislokasi atau keseleo dengan angka $10 \%$ pada kasus ini sering terjadi pada saat latihan dryland atau latihan tanpa sepatu roda.Pada beberapa teknik yang harus dilakukan atlet banyak yang mengharuskan atlet untuk melakukan kombinasi lompatan keatas dan kesamping kanan kiri.Posisi saat mendarat sangatlah berpengaruh pada kondisi ankle apabila ankle tidak benarbenar siap dan kuat makadislokasi bisa terjadi atau jika atlet tidak fokus dalam melakukan gerakan tersebut. Pada penelitiannya Malanga dan Stuart yang di kutip oleh Shauna Sheker dan Erin Cassell (2002: 14) menyebutkan bahwa 3.6 \% dari keseluruhan cedera yang terjadi pada in-line skater merupakan cedera ankle.

Pada teknik dasar menggunakan sepatu posisi tungkai harus di tekuk hingga 60 derajat yang menyebabkan kontraksi pada sebagian otot betis, selaian itu apabila melakukan teknik dryland skate memerlukan waktu sesingkat mungkin untuk melakukan gerakan-gerakannya. Lecet dan abrasi kulit biasanya terjadi karena adanya gesekan antara kulit dengan aspal lintasan, sedangkan memar biasanya karena lutut berbenturan dengan benda-benda tumpul dan keras seperti frame pada sepatu roda atau dengan pagar pembatas lintasan.Keseleo menunjukkan angka $18 \%$, cedera ini sering dikeluhkan atlet ketika melakukan dryland skate atau latihan teknik namun tidak menggunakan sepatu roda. Menurut Malanga da Struart yang di kutip oleh Shauna sheker dan Erin Cassell (2002: 14) menyebutkan bahwa sebagian dari cedera yang terjadi pada lutut terjadi pada bilateral anterior collateral ligamen dan medial collateral ligament.

Pada kasus ini juga dapat dikatan penyebabnya hampir sama dengan cedera lutut karena pada otot paha lebih banyak melakukan gerakan isotonis dimana kontraksi otot yang harus 
dilakukan secara kontinyu dan dalam waktu yang cukup lama, apabila tingkat kelelahan otot tidak begitu diperhatikan oleh pelatih, maka kram/ kejang otot ini sangat besar resikonya. Lalu memar 17 \%.Pada luka memar yang terjadi pada paha ini lebih sering disebabkan karena benturan atau menabrak pagar pembatas karena untuk menghindari atlet didepannya yang terjatuh, keseimbangan pada saat menghindar yang tidak baik itulah yang menyebabkan atlet menebrak pagar pembatas lintasan.

Cedera yang terjadi akibat benturan daerah panggul dengan benda tumpul seperti pagar pembatas dan aspal. Benturan tersebut diakibatkan karena atlet mengalami hilang keseimbangan kemudian tidak bisa mengontrol laju kecepatannya sehingga terjatuh atau menabrak pagar pembatas lintasan.Hilangnya keseimbangan atlet juga bisa di sebabkan oleh kurang bersihnya lintasan seperti masih adanya daun-daun kering yang bertebaran, kondisi lintasan yang sedikit basah dan juga tabrakan antar atlet sendiri. Kasus degradasi kulit ini akan lebih parah jika terjadi pada lintasan yang tidak begitu rata dan halus. Cedera panggul yang terjadi hampir sesuai dengan yang dikukakan oleh Shauna sheker dan Erin Cassell (2002: 14) yang mengemukakan bahwa cedera anggota tubuh bagian bawah meliputi daerah panggul, ankle, lutut, dan tungkai bawah.

Pada kasus kram atau kejang otot yang terjadi karena posisi saat meroda atlet harus membungkuk dan menekuk lutut serendah mungkin untuk mengurangi benturan antara angina dengan tubuh agar gerakanya lebih aerodinamis. Karena posisi itu yang cukup lama sehingga atlet sering mengeluhkan nyeri pada bagian pinggang atau tingkat ketegangan otot tinggi akibat tertarik dalam waktu yang cukup lama, hal ini terutama sering di keluhkan saat melakukan lomba di nomor jarak jauh (5000 atau 10.000 meter). Memar $26 \%$ dan lecet $21 \%$, hampir sama seperti pada memar dan lecet di lokasi cedera sebelumnya dimana kasus ini terjadi akibat benturan atau terjatuh. Memar terjadi karena pada saat terjatih posisi badan terpelanting sehingga pinggang yang pertama kali berbenturan dengan aspal lintasan.

Luka lecet dan memar mendominasi cedera pada siku karena pada setiap kali atlet terjatuh refleks yang harus dilakukan adalah menjatuhkan badan kedepan sehingga siku mau tidak mau harus bergesekan dengan aspal lintasan, dan apabila sampai jatuh terseret terjadilah abrasi kulit. Keseleo 6\%, Kasus keseleo pada siku bisa terjadi karena pada saat jatuh tangan yang menumpu tidak begitu kuat sehingga siku terpelintrir dan menyebabkan dislokasi atau yang lebih parah lagi adalah fraktur. Menurut Called an Eaton yang di kutip oleh Shuana Sheker dan Erin Cassell (2002: 14) menjelesakan bahwa anggota tubuh bagian atas yang rawan cedera $11 \%$ nya meliputi bagian siku. Hal ini juga diperkuat oleh Jascha De Nooirjedkk 
(2004: 178) yang menyebutkan bahwa 8\% dari cedera yang terjadi pada pesepatu roda merupakan cedera siku.

Terkadang untuk atlet pada usia 13-15 tahun dengan jam tanding yang cukup banyak yang sering meremehkan untuk tidak menggunakan sarung tangan. Pada kasus ini cedera yang paling parah yang bisa terjadi adalah fraktur karena hampir beberapa kasus fraktur yang di temui peneliti di lapangan adalah terjadi karena pada saat terjatuh pergelangan tangan yang digunakan untuk melakukan pendaratan atau tumpuan tidaklah kuat sehingga benturan yang terjadi menyebabkan fraktur. Shauna Sheker dan Erin Cassell (2002: 14) mengemukakan bahwa tipe jatuhnya seorang in-line skater yang menyanggakan tangannya saat jatuh sehingga melebihi dari kelenturan otot lengan sehingga terjadi benturan yang keras yang menyebabkan cedera ada pergelangan tangan. Jascha De Nooijer dkk ( 2004: 178) menyebutkan bahwa di belanda pada tahun 2000, $36 \%$ dari keseluruhan cedera pada pesepatu roda terjadi pada pergelangan tangan.

\section{KESIMPULAN}

Faktor yang menyebebakan cedera para atlet sepatu roda sebagian besar disebabkan oleh jatuh dan benturan. Dalam prorses sebelum terjatuh dan benturan itu desebabkan oleh beberapa faktor, yang paling sering yaitu terpeleset dan salah mengambil tikungan dimana dari terpeleset dan salah mengambil tikungan itu bisa menyebabkan tabrakan antar atlet, si atlet yang berusaha untuk menghindar justru menabrak pagar pembatas lintasan. Terpelesetnya atlet di lintasan di pengaruhi oleh faktor kebersihan lintasan dari sampah daun kering atau sampah-sampah lain yang mudah terbawa angin, kondisi setelah hujan menyebabkan lintasan yang basah sehingga permukaan lintasan licin dan gaya gesek antara roda dengan permukaan lintasan menjadi tidak sempurna, selain itu juga setelah hujan reda terkadang meninggalkan pasir dipinggir lintasan itu juga dapat menyebabkan si atlet terpeleset. Penggunaan alat keamanan seperti pelindung lutut (knee pad) danpelindung siku (elbow pad) masih kurang hal ini menyebabkan luka lecet, abrasi kulit dan memar memperoleh persentase yang cukup tinggi pada daerah tersebut.

Kontur dan bentuk lintasan juga juga sangat berpengaruh dalam memngambil tikungan.D i beberapa kota yang menyelenggarakan perlombaan sepatu roda terkadang menyediakan lintasan yang dapat dikatakan berbentuk kotak hal ini menjadi jadi kendala untuk para atlet karena tikungan yang dilewati sangatlah tajam. Ditambah lagi ketika kondisi aspal yang 
sedikit bergelombang dengan tingkat kualiatas aspal yang tidak terlalu halus meneyebabkan ketidaknyamanan tersendiri untuk melakukan perlombaan. Dalam hal mengambil tikungan ini pengalaman para atlet juga berpengaruh.

Latihan dengan intensitas berat dalam waktu yang cukup lama juga sangat mempengaruhi proses terjadinya cedera para atlet. Recovery yang kurang menyebabkan tingkat stress otot dan psikis sangat tinggi. Ketika otot telah mengalami kelelahan dan kurang istirahat maka kram atau kejang otot sangat memungkinkan dialami atlet, selain itu juga yang lebih parah lagi pada bagian persendian juga bisa menyebabkan sprain pada ligamentum terutama di bagian lutut karena lutut sangat berperan besar dalam olahraga sepatu roda.

\section{DAFTAR PUSTAKA}

Ahmad Zulfa. (2014). Sejarah In-line Skate.diakses dari www.ahmadzulfa33.blogspot.com pada tanggal 22 Maret 2014 pukul 23.26 wib.

Alexander Bont. (2000). Landtraining: Off Skate. diakses dari www.bont.com/news/ featurearticles/landtraining.htm pada 30 april 2014 jam 12.47.

American Accademic of Orthopedic Surgeon. (2007). Sprain And Strain: What's The Defferent. Diakses dari http://orthoinfo.aaos.org pada 23 maret 2014 pukul 20.30.

Arif Setiawan.( 2011). Faktor Timbulnya Cedera Olahraga. Jurnal: Media Ilmu Keolahragaan Indonesia. Volume 1.Universitas Negeri Semarang.

Bambang Priyonoadi. Cedera Achilles Dan Perawatanya. Diakses dari staff.uny.ac.id/sites/default/files/131453189/Cedera Achilles \& Perawatannya. pdf tanggal 10 September 2014 jam 21.33 .

Bernard Bloch. (1978). Fraktur dan Dislokasi. Alih bahasa: Timbang M. Simandjutak dkk. Yogyakarta: Essentia Medica.

B.M Wara Kushartanti. (2014). Patofisiologi Cedera. Diakses dari http://staff.uny.ac.id/sites/default/files/tmp/PATOFISIOLOGI\%20CEDERA.pdf diakses 3 november 2014 jam 14.08 WIB.

Cerika Rismayanthi. (2014). Bahan Ajar PPC: Hakikat Cedera Olahraga. Diakses dari http://staff.uny.ac.id/sites/default/files/pendidikan/Cerika\%20Risma

yanhi,\%20S.Or./PPC-Cedera\%20Olahraga\%281\%29.pdf tanggal 10 September 2014 jam 21.15 .

Chris Weaver. US Speed Skating: Basic Skills Manual. Diakses dari http://iceskatingresource.org/basicspeedskatingmanual.pdfdiakses pada 21 September 2013 jam 23.45 wib. 
Giam C. K. dan Teh K. C. (1993). Ilmu Kedokteran Olahraga. Alih bahasa: Hartono Satmoko. Jakarta: Binarupa Akasara.

Health, Care UK (2009).Orthopaedic Surgery and Sport Medicine: Combined Knee Ligament Sprain. UK

Inline Skating Resource Center.(2014). Inline Skating Safety Statistics. Diakses dari http://InlineSkatingSafetyStatistics.htm pada 21 Oktober 2014 pukul 23.00 wib.

Jascha De Nooijer, Maaike De Wit, Ingrid Steenhuis. (2004). Why Young Dutch Inline skaters Do (Not) Use Protection Equipment. Jurnal European Journal Of Public Health. 14. Hal. $178-181$

Lynn Millar.A. (2011).Sprain, Strain and Tears. American College of Sport Medicine

NIAMS. (2009). What are Sprain and Strain?US Department Health And Human Sevirce. USA

Schieber, R. A., Branche-Dorsey, C. M., \& Ryan, G. W. (1994). Comparison of in-line skating injuries with rollerskating and skateboarding injuries. JAMA, 271(23), 18561858.

Shauna Sheker dan Erin Cassell. (2002). In-Line Skating: A Review Of The Literature. Monash University.

Sri Sumartiningsih. (2012). Cedera Keseleo Pada Pergelangan Kaki (Ankle Sprain).Jurnal Media Ilmu Kelolahragaan Indonesia (Volume 2 Edisi 1). Hlm. 54-58. Universitas Negeri Semarang.

Suftini.(2004). Cedera Pada Extremitas Superior.Fakultas Kedokteran USU 